\title{
Teaching NeuroImage: Immune Checkpoint Inhibitor-Related Fasciitis and Myositis With Perifascicular Atrophy
}

Timothy R. Fullam, MD, Nathan McGraw, MD, Matthew Grainger, Mazen M. Dimachkie, MD, and Swathy Chandrashekhar, MD

Neurology ${ }^{\circledR}$ 2021;97:1049-1050. doi:10.1212/WNL.0000000000012577

Figure Immune Checkpoint Inhibitor-Related Fasciitis and Myositis With Perifascicular Atrophy

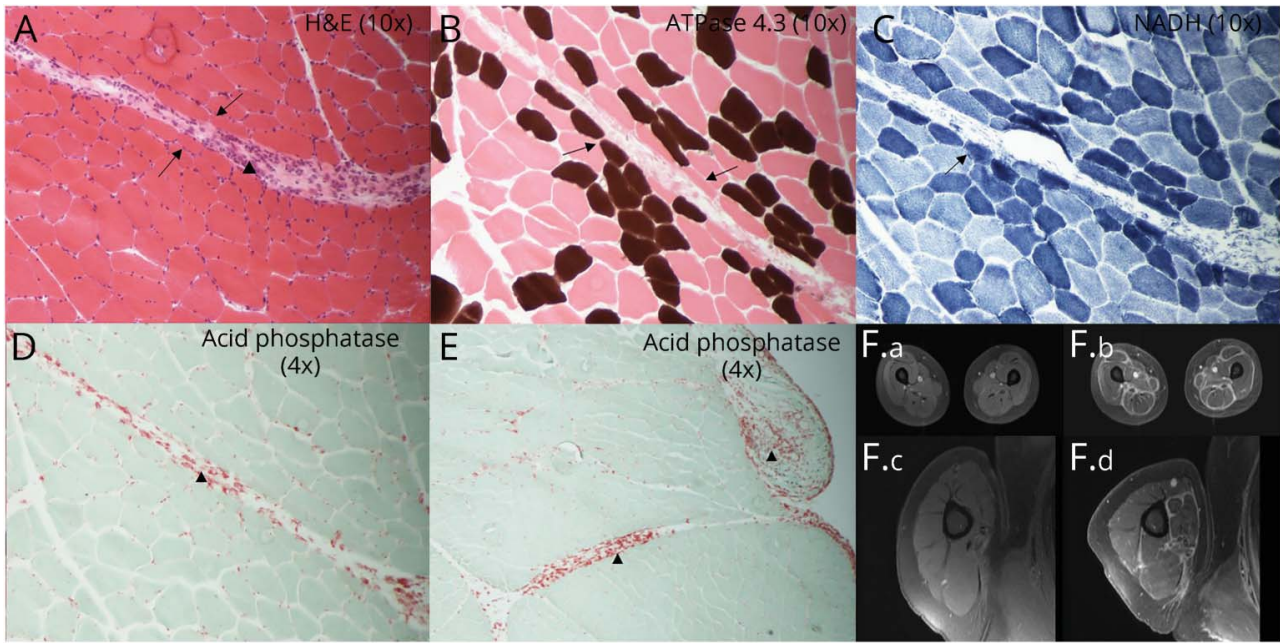

Perifascicular atrophy noted on H\&E (A), ATPase (B), and nicotinamide adenine dinucleotide (C) stains (arrow) with fascial, perimysial, and perivascular inflammatory infiltrates on H\&E (A, arrowhead) and acid phosphatase (D, E, arrowheads). Precontrast and postcontrast MRI of the lower extremities (F.a, F.b) and upper extremities (F.c, F.d) with fascial and muscle enhancement.

\section{Case Summary}

A 58-year-old man with melanoma treated with ipilimumab/nivolumab presented with pain, limited joint mobility, and proximal weakness without oculobulbar weakness, dyspnea, or rash. EMG demonstrated positive sharp waves, fibrillations, and myopathic units. Extremity MRI showed diffuse fascial and mild muscle enhancement consistent with fasciitis/mild myositis (Figure). Creatinine kinase was normal. PET-CT demonstrated diffusely fluorodeoxyglucose-avid lymph nodes and muscles; lymph node biopsy revealed granulomatous inflammation suggesting immune checkpoint inhibitor-related inflammatory reaction. Biceps biopsy demonstrated perifascicular atrophy (PA) and fascial/perimysial perivascular inflammation (Figure).

Histopathologic findings of immune checkpoint inhibitor-related myositis initially included necrosis, macrophagy, and endomysial inflammation. The spectrum has expanded to include perimysial perivascular inflammation and PA tendency. ${ }^{1,2}$
Correspondence

Dr. Fullam

trfullam23@gmail.com

\section{MORE ONLINE}

\section{Teaching slides}

links.lww.com/WNL/

B481 


\section{Study Funding}

The authors report no targeted funding.

\section{Disclosure}

T.R. Fullam reports no disclosures relevant to the manuscript; N. McGraw reports no disclosures relevant to the manuscript; M. Grainger reports no disclosures relevant to the manuscript; S. Chandrashekhar reports no disclosures relevant to the manuscript; M.M. Dimachkie reports no disclosures relevant to the manuscript with full disclosures up to date on the AAN website. Go to Neurology.org/ $\mathrm{N}$ for full disclosures.

Appendix Authors

\begin{tabular}{lll}
\hline Name & Location & Contribution \\
\hline $\begin{array}{l}\text { Timothy Fullam, } \\
\text { MD }\end{array}$ & $\begin{array}{l}\text { Department of Neurology, } \\
\text { The University of Kansas } \\
\text { Medical Center, Kansas }\end{array}$ & $\begin{array}{l}\text { Analysis of biopsy, review } \\
\text { of neuroimaging, and } \\
\text { drafting the manuscript }\end{array}$ \\
& City & \\
\hline
\end{tabular}

Appendix (continued)

\begin{tabular}{lll}
\hline Name & Location & Contribution \\
\hline $\begin{array}{l}\text { Nathan McGraw, } \\
\text { MD }\end{array}$ & $\begin{array}{l}\text { Department of Neurology, } \\
\text { The University of Kansas } \\
\text { Medical Center, Kansas City }\end{array}$ & $\begin{array}{l}\text { Analysis of biopsy and } \\
\text { critical review of the } \\
\text { manuscript }\end{array}$ \\
\hline $\begin{array}{l}\text { Matthew } \\
\text { Grainger }\end{array}$ & $\begin{array}{l}\text { Department of Neurology, } \\
\text { The University of Kansas } \\
\text { Medical Center, Kansas } \\
\text { City }\end{array}$ & $\begin{array}{l}\text { Preparation and } \\
\text { processing of muscle } \\
\text { biopsy and critical review } \\
\text { of the manuscript }\end{array}$ \\
$\begin{array}{l}\text { Mazen M. } \\
\text { Dimachkie, MD }\end{array}$ & $\begin{array}{l}\text { Department of Neurology, } \\
\text { The University of Kansas } \\
\text { Medical Center, Kansas } \\
\text { City }\end{array}$ & $\begin{array}{l}\text { Analysis of biopsy and } \\
\text { critical review of the } \\
\text { manuscript }\end{array}$ \\
\hline $\begin{array}{l}\text { Swathy } \\
\text { Chandrashekhar, } \\
\text { MD }\end{array}$ & $\begin{array}{l}\text { Department of Neurology, } \\
\text { The University of Kansas } \\
\text { Medical Center, Kansas } \\
\text { City }\end{array}$ & $\begin{array}{l}\text { Patient management, } \\
\text { analysis of biopsy, and } \\
\text { critical review of the } \\
\text { manuscript }\end{array}$ \\
\hline
\end{tabular}

\section{References}

1. Matas-García A, Milisenda JC, Selva-O’Callaghan A, et al. Emerging PD-1 and PD-1L inhibitors-associated myopathy with a characteristic histopathological pattern. Autoimmun Rev. 2020;19(2):102455.

2. Touat M, Maisonobe T, Knauss S, et al. Immune checkpoint inhibitor-related myositi and myocarditis in patients with cancer. Neurology. 2018;91(10):e985-e994.

\section{Subspecialty Alerts by E-mail!}

Customize your online journal experience by signing up for e-mail alerts related to your subspecialty or area of interest. Access this free service by clicking on the "My Alerts" link on the home page. An extensive list of subspecialties, methods, and study design choices will be available for you to choose from-allowing you priority alerts to cutting-edge research in your field!

\section{Disputes \& Debates: Rapid Online Correspondence}

The editors encourage comments on recent articles through Disputes \& Debates:

Access an article at Neurology.org/ $\mathrm{N}$ and click on "MAKE COMMENT" beneath the article header.

Before submitting a comment to Disputes \& Debates, remember the following:

- Disputes \& Debates is restricted to comments about articles published in Neurology within 6 months of issue date

- Read previously posted comments; redundant comments will not be posted

- Your submission must be 200 words or less and have a maximum of 5 references; the first reference must be the article on which you are commenting

- You can include a maximum of 5 authors (including yourself) 


\section{Neurology}

\section{Teaching NeuroImage: Immune Checkpoint Inhibitor-Related Fasciitis and Myositis With Perifascicular Atrophy}

Timothy R. Fullam, Nathan McGraw, Matthew Grainger, et al.

Neurology 2021;97;1049-1050 Published Online before print July 29, 2021

DOI 10.1212/WNL.0000000000012577

This information is current as of July 29, 2021

\begin{tabular}{|c|c|}
\hline $\begin{array}{l}\text { Updated Information \& } \\
\text { Services }\end{array}$ & $\begin{array}{l}\text { including high resolution figures, can be found at: } \\
\text { http://n.neurology.org/content/97/22/1049. full }\end{array}$ \\
\hline References & $\begin{array}{l}\text { This article cites } 2 \text { articles, } 1 \text { of which you can access for free at: } \\
\text { http://n.neurology.org/content/97/22/1049.full\#ref-list-1 }\end{array}$ \\
\hline Subspecialty Collections & $\begin{array}{l}\text { This article, along with others on similar topics, appears in the } \\
\text { following collection(s): } \\
\text { Chemotherapy-tumor } \\
\text { http://n.neurology.org/cgi/collection/chemotherapytumor } \\
\text { MRI } \\
\text { http://n.neurology.org/cgi/collection/mri } \\
\text { Muscle disease } \\
\text { http://n.neurology.org/cgi/collection/muscle_disease }\end{array}$ \\
\hline Permissions \& Licensing & $\begin{array}{l}\text { Information about reproducing this article in parts (figures,tables) or in } \\
\text { its entirety can be found online at: } \\
\text { http://www.neurology.org/about/about_the_journal\#permissions }\end{array}$ \\
\hline Reprints & $\begin{array}{l}\text { Information about ordering reprints can be found online: } \\
\mathrm{http} / / / \mathrm{n} \text {.neurology.org/subscribers/advertise }\end{array}$ \\
\hline
\end{tabular}

Neurology ${ }^{\circledR}$ is the official journal of the American Academy of Neurology. Published continuously since 1951, it is now a weekly with 48 issues per year. Copyright (C 2021 American Academy of Neurology. All rights reserved. Print ISSN: 0028-3878. Online ISSN: 1526-632X.

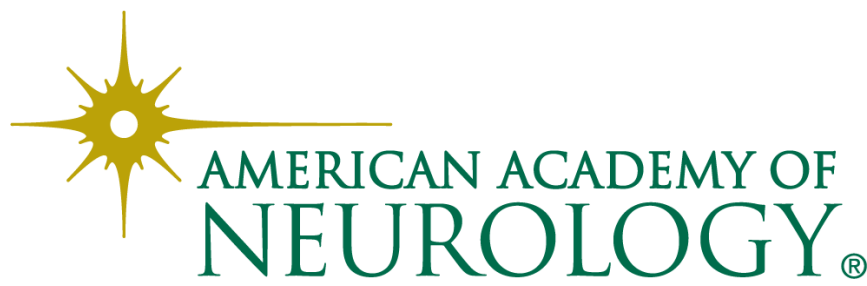

